\title{
PEMANFAATAN DAUN HARENDONG (Melastoma malabathricum) SEBAGAI PEWARNA ALAMI UNTUK KAIN KATUN
}

Utilization of Harendong (Melastoma malabathricum) Leaves as Natural Dyes for Cotton Fabric

\author{
Enur Azizah ${ }^{1}$ dan Alex Hartana ${ }^{2}$ \\ ${ }^{1}$ Program Studi Biologi Tumbuhan, Departemen Biologi, Fakultas Matematika dan Ilmu Pengetahuan Alam, \\ Sekolah Pascasarjana Institut Pertanian Bogor, Bogor 16680 \\ E-mail: e.azizah08@gmail.com \\ ${ }^{2}$ Departemen Biologi, Fakultas Matematika dan Ilmu Pengetahuan Alam, \\ Institut Pertanian Bogor, Bogor 16680 \\ E-mail: ahartana301249@gmail.com \\ Tanggal Masuk: 21 November 2017 \\ Tanggal Revisi: 23 Maret 2018 \\ Tanggal disetujui: 23 Maret 2018
}

\begin{abstract}
ABSTRAK
Meningkatnya kesadaran di kalangan masyarakat tentang efek bahaya dari penggunaan zat pewarna sintetis membuat eksplorasi zat pewarna alami terus dilakukan. Banyak pewarna yang dihasilkan dari tumbuhan dan digunakan untuk pewarnaan tekstil. Penelitian dilakukan untuk mencari potensi dari daun harendong (Melastoma malabathricum) dalam menghasilkan pewarna alami untuk kain katun. Optimalisasi pewarnaan kain dilakukan dengan penambahan mordan berupa tawas $\left[\mathrm{KAl}\left(\mathrm{SO}_{4}\right)_{2} \cdot \mathrm{I}_{2} \mathrm{H}_{2} \mathrm{O}\right]$, kapur sirih $\left(\mathrm{Ca}(\mathrm{OH})_{2}\right)$, dan tunjung $\left(\mathrm{FeSO}_{4}\right)$ saat proses fiksasi pada kain katun. Kain katun yang telah diwarnai diidentifikasi warnanya menggunakan RGB (Red Green Blue) Color Chart Reader. Kain katun yang diwarnai dengan ekstrak daun harendong menghasilkan warna Banana (\#E3CF57). Pemberian mordan saat fiksasi berpengaruh terhadap warna kain. Kain yang difiksasi menggunakan tawas berwarna Khaki 1 (\#FFF68F), sedangkan yang difiksasi menggunakan kapur sirih berwarna Lightgoldenrod 1 (\#FFEC8B) dan kain yang difiksasi menggunakan tunjung berwarna Sgi Gray 36 (\#5B5B5B). Penambahan mordan juga memberikan pengaruh baik terhadap ketahanan luntur warna pada kain katun akibat pengaruh pencucian dan paparan sinar matahari. Daun harendong berpotensi baik dalam mewarnai kain katun.
\end{abstract}

Kata Kunci: ketahanan luntur, Melastoma malabathricum, mordan, pewarna alami.

\begin{abstract}
Due to increasing awareness among people about harmful effects of synthetic dyes, products obtained from natural materials are continuously being explore. Many dyes are obtained from plants are used in dyeing technique on textiles. The study was to explore the potency of harendong (Melastoma malabathricum) leaves in producing natural dyes for cotton fabric. The dyeing process was carried out with optimization by addition of mordants i.e alum [ $\left.\mathrm{KAl}\left(\mathrm{SO}_{4}\right)_{2} \cdot \mathrm{I}_{2} \mathrm{H}_{2} \mathrm{O}\right]$, slaked lime $\left(\mathrm{Ca}(\mathrm{OH})_{2}\right)$, and ferrous sulphate $\left(\mathrm{FeSO}_{4}\right)$ on cotton fabric fixation. The dyed samples were identified by $\mathrm{RGB}$ (Red Green Blue) Color Chart Reader. The color of cotton fabric which was colored by extract of harendong leaves was Banana (\#E3CF57). Color yield values were found to be influenced by addition of mordants on fixation. The color of cotton fabric which fixated by alum was Khaki 1 (\#FFF68F), Lightgoldenrod 1 (\#FFEC8B) of slaked lime-fixated, and Sgi Gray 36 (\#5B5B5B) of ferrous sulphatefixated. The addition of mordants were also influenced good fastness to washing and light fastness for the sample dyed. Harendong leaves have good potentiality as natural dyes for dyeing cotton fabrics.
\end{abstract}

Keywords: fastness properties, Melastoma malabathricum, mordant, natural dye. 


\section{PENDAHULUAN}

Penggunaan zat warna sintetis dalam industri tekstil saat ini telah banyak digunakan karena harganya yang relatif lebih murah, memiliki warna yang bervariasi, dan memiliki ketahanan luntur yang lebih baik dibandingkan dengan zat pewarna alami (El-Nagar et.al., 2005; Iqbal et.al., 2008). Namun, menghadapi abad ke21 yang berorientasi lingkungan, belakangan ini masyarakat khawatir terhadap dampak lingkungan dari penggunaan zat warna sintetis. Hal tersebut dikarenakan dapat mengganggu kesehatan berupa ancaman kanker dan bersifat nondegradable sehingga tidak ramah terhadap lingkungan (Ventura-Camargo \& MarinMorales, 2013; Goodarzian \& Ekrami, 2010; (Jothi, 2008). Kondisi demikian dapat dijadikan tuas untuk mengembalikan peranan zat pewarna alami (Sutara, 2009), karena pewarna alami merupakan salah satu pilihan yang menjanjikan untuk pengembangan dalam pewarnaan tekstil yang lebih ramah lingkungan (Uddin, 2015). Selain ramah lingkungan, penggunaan zat pewarna alami dalam industri tekstil memiliki potensi pasar yang tinggi sebagai komoditas unggulan produk Indonesia dengan daya tarik pada karakteristik yang unik, etnik, dan eksklusif sehingga membuat nilai jualnya menjadi lebih tinggi.

Harendong sebagai pewarna alami tekstil belum tersedia. Daun merupakan salah satu organ tumbuhan yang ketersediaan dan kelimpahannya lebih tinggi dibandingkan dengan organ tumbuhan lainnya, sehingga perlu dicari potensinya untuk menambah daftar sumber pewarna alami yang dapat dijadikan pewarna alternatif dalam pewarnaan kain, terutama batik. Penelitian ini bertujuan untuk mengeksplorasi potensi daun harendong ( $M$. malabathricum dalam menghasilkan
Melastoma malabathricum) atau yang dikenal sebagai Harendong atau Senduduk (Indonesia), Singapore Rhododendron (Singapura) atau Sendudok (Malaysia) merupakan tumbuhan semak dari suku Melastomaceae yang banyak tumbuh di berbagai negara, seperti Sri Lanka dan Asia Tenggara, termasuk Indonesia, Filipina, Taiwan, Papua Nugini, Australia, dan Amerika (See, 2008; Vankar et.al., 2009).

Harendong banyak tumbuh dan tersebar di hutan Indonesia. Tumbuhan ini tumbuh liar pada tempat-tempat yang mendapat sinar matahari yang cukup, seperti di lereng gunung, semak, lapangan yang tidak terlalu gersang, atau ditanam di daerah objek wisata sebagai tanaman hias (Gholib, 2009). Warna bunganya yang menarik membuat masyarakat menjadikannya sebagai tanaman hias dan sumber pewarna alami yang potensial (Janna et.al., 2006). Warna yang ditimbulkan disebabkan oleh adanya antosianin dan tanin yang kemunculannya tidak terbatas pada bunga tetapi mencakup semua bagian tanaman (See, 2008).

Antosianin pada bunga harendong telah banyak digunakan sebagai pewarna makanan (Janna et.al., 2006), begitu pula dengan buahnya yang digunakan dalam industri tekstil untuk pewarnaan kain katun (Vankar et.al., 2009). Namun, penelitian yang melaporkan tentang pemanfaatan daun pewarna alami untuk pewarnaan kain katun belum tersedia.

\section{METODOLOGI PENELITIAN}

\section{Bahan dan Peralatan}

Bahan yang digunakan pada penelitian ini yaitu daun harendong (Melastoma malabathricum); TRO (Turkey Red Oil); soda abu $\left(\mathrm{Na}_{2} \mathrm{CO}_{3}\right)$; beberapa jenis mordan untuk fiksasi yaitu tawas $\left[\mathrm{KAl}\left(\mathrm{SO}_{4}\right)_{2} \cdot \mathrm{I}_{2} \mathrm{H}_{2} \mathrm{O}\right]$, kapur sirih $\left(\mathrm{Ca}(\mathrm{OH})_{2}\right)$, 
dan tunjung $\left(\mathrm{FeSO}_{4}\right)$; dan kain katun jenis poplin sebagai media untuk uji pewarnaan.

Peralatan yang digunakan yaitu timbangan, alat pemanas, kertas saring, batang pengaduk, dan cawan petri.

\section{Pelaksanaan Penelitian}

\section{Ekstraksi Zat Warna Alam}

Zat pewarna alami diperoleh dengan mengekstrak daun harendong. Daun dicuci selanjutnya dikeringkan dalam oven dan dihaluskan hingga menjadi serbuk. Ekstraksi dilakukan dengan menggunakan metode konvensional yaitu dengan merebus serbuk bahan dalam air dengan rasio antara serbuk daun dan air yaitu 1:10 (massa serbuk daun dalam gram, volume air dalam mililiter) sampai larutan berkurang menjadi 1/3 bagian. Ekstrak yang dihasilkan didiamkan selama satu malam selanjutnya disaring mengggunakan kertas saring (Uddin, 2015).

\section{Pewarnaan Kain Katun dengan Zat Pewarna Alami}

Sebelum proses pencelupan warna, kain katun direndam dalam larutan TRO (Turkey Red Oil) 2 g/l selama 30 menit, selanjutnya kain dicuci sampai bersih dan dikeringkan. Kain direbus dalam 2 liter air yang mengandung 10 gram tawas dan 3 gram soda abu $\left(\mathrm{Na}_{2} \mathrm{CO}_{3}\right)$ selama 30 menit. Setelah itu, api dipadamkan dan kain didiamkan dalam larutan tersebut selama satu malam dan selanjutnya kain dicuci dan dikeringkan. Kain dicelupkan ke dalam ekstrak zat warna alam selama 15 menit. Pencelupan tersebut dilakukan secara berulang sebanyak 3 kali celupan dan dikeringkan. Selanjutnya kain difiksasi menggunakan mordan yaitu larutan tawas [KAl $\left.\left(\mathrm{SO}_{4}\right)_{2} \cdot \mathrm{I}_{2} \mathrm{H}_{2} \mathrm{O}\right] 70 \mathrm{~g} / 1$, kapur sirih $\left(\mathrm{Ca}(\mathrm{OH})_{2}\right) 50 \mathrm{~g} / \mathrm{l}$, dan tunjung $\left(\mathrm{FeSO}_{4}\right) 20$ g/l. Selanjutnya, kain dicuci bersih dan dikeringkan.

Kain yang digunakan sebagai media untuk uji pewarnaan dalam penelitian ini adalah kain katun jenis poplin. Katun poplin terbuat dari serat kapas yang memiliki serat yang lebih rapat, lentur, dan tidak mudah kusut, sehingga digolongkan ke dalam jenis katun dengan kualitas unggul. Jenis kain ini memiliki kemampuan untuk menyerap bahan alami maupun kimia dengan baik (Russanti, 2007).

\section{Identifikasi Warna}

Kain yang telah melalui proses pencelupan dan fiksasi diidentifikasi warnanya menggunakan Red Green Blue (RGB) Color Chart Reader (http://cloford.com/resources/colours/500col .htm).

\section{Uji Stabilitas Warna}

Warna kain katun diuji ketahanan luntur warna terhadap pengaruh pencucian dengan sabun dan ketahanan luntur terhadap sinar terang matahari. Masing-masing perlakuan dilakukan sebanyak 3 kali ulangan. Metode pengujian mengacu pada SNI ISO 105 C06 - 2010 dan SNI ISO 105 - B01: 2010 (Pujilestari, 2014).

\section{HASIL DAN PEMBAHASAN}

Ekstraksi daun harendong menghasilkan warna yang dapat digunakan untuk mewarnai kain katun. Kain katun yang diwarnai dengan ekstrak daun harendong menghasilkan warna Banana (\#E3CF57). Warna tersebut dihasilkan tanpa melalui proses fiksasi, sedangkan kain yang difiksasi menggunakan tawas $\left[\mathrm{KAl}\left(\mathrm{SO}_{4}\right)_{2} \cdot \mathrm{I}_{2} \mathrm{H}_{2} \mathrm{O}\right]$ berwarna Khaki 1 
(\#FFF68F) yang lebih terang dibandingkan dengan kain yang tanpa mengalami fiksasi.

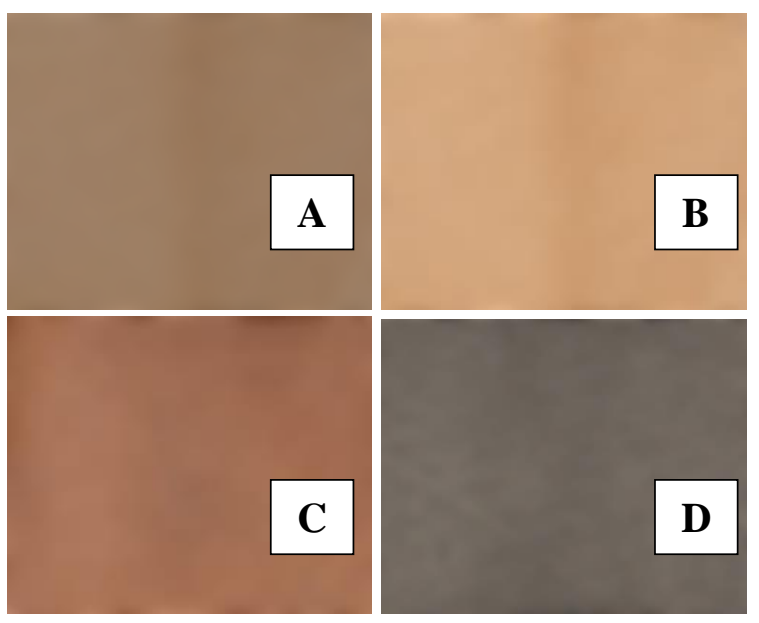

Gambar 1. Warna yang dihasilkan oleh daun harendong. A. Kain katun tanpa fiksasi. B. Kain dengan fiksasi tawas. C. Kain dengan fiksasi kapur sirih. D. Kain dengan fiksasi tunjung.

Kain yang difiksasi menggunakan kapur sirih $\left(\mathrm{Ca}(\mathrm{OH})_{2}\right)$ menimbulkan warna lebih pekat yaitu berwarna Lightgoldenrod 1 (\#FFEC8B), sedangkan kain yang difiksasi menggunakan tunjung $\left(\mathrm{FeSO}_{4}\right)$ menghasilkan warna gelap yaitu Sgi Gray 36 (\#5B5B5B) (Gambar 1). Hal ini sejalan dengan penelitian-penelitian sebelumnya yang menyatakan bahwa kain yang difiksasi menggunakan tunjung akan menimbulkan warna yang mengarah pada warna kehitamhitaman (Samanta \& Agarwal, 2009; Sobandi, 2011; Vadwala \& Kola, 2017), kapur sirih menimbulkan warna menjadi lebih pekat, sedangkan tawas menimbulkan warna menjadi lebih terang dari warna aslinya sebelum mengalami fiksasi.

Saat proses pewarnaan terjadi penyerapan zat warna ke dalam serat kain, namun seringkali ada zat yang menghalangi penyerapan zat warna tersebut terhadap permukaan kain, seperti sisa lemak yang yang ditambahkan saat proses pembuatan kain dan sisa kotoran lain dari mesin (Moiliet \& Collie, 1951). Oleh karena itu, diperlukan penambahan bahan pembantu untuk mendorong zat warna sehingga terjadi difusi zat warna dari permukaan ke dalam serat kain (Bhattacharya \& Shah, 2000; Temani et.al., 2011; Uddin, 2014).

Warna yang ditimbulkan pada kain katun menggunakan ekstrak daun harendong dipengaruhi oleh jenis mordan yang digunakan dalam proses fiksasi. Jenis-jenis mordan yang biasa digunakan dalam proses fiksasi yaitu mordan logam - mordan yang berasal dari garam logam seperti $\mathrm{KAl}(\mathrm{SO} 4) 2 . \mathrm{I}_{2} \mathrm{H}_{2} \mathrm{O}, \quad \mathrm{Ca}(\mathrm{OH})_{2}, \quad \mathrm{FeSO} 4$, $\mathrm{CuSO} 4, \quad \mathrm{SnCl}_{2}, \quad \mathrm{~K}_{2} \mathrm{CrO}_{7}, \quad \mathrm{Na}_{2} \mathrm{CO}_{3}$, $\mathrm{CH}_{3} \mathrm{COOH}, \mathrm{Fe}\left(\mathrm{NO}_{3}\right)_{3}$; tanin - myrobolan dan sumac; mordan minyak - Turkey Red Oil (TRO) (Singh \& Srivastava, 2017). Dalam penelitian ini menggunakan 3 jenis mordan dari kelompok logam kompleks, yaitu tawas $\left[\mathrm{KAl}(\mathrm{SO} 4)_{2} \cdot \mathrm{I}_{2} \mathrm{H}_{2} \mathrm{O}\right]$, kapur sirih $\left(\mathrm{Ca}(\mathrm{OH})_{2}\right)$ dan tunjung (FeSO4). Ketiga jenis mordan tersebut dipilih karena banyak digunakan, harganya yang terjangkau, dan mudah didapat di pasaran (Wijana et.al., 2015). Selain menimbulkan variasi warna yang beragam, penambahan mordan saat fiksasi juga mengakibatkan kain yang terwarnai menjadi tahan terhadap pengaruh pencucian dan sinar terang matahari. Hal tersebut terlihat dari adanya perbedaan ketahanan luntur antara kain yang diberi penambahan mordan dengan kain yang tidak diberi penambahan mordan (Tabel 1). Fiksasi merupakan tahapan penting dalam proses pencelupan warna, karena tahapan tersebut dilakukan untuk membangkitkan dan mengunci warna yang telah dihasilkan (Prayitno et.al., 2014). Penggunaan mordan dalam proses pewarnaan akan membuat warna menjadi tidak mudah luntur dan tahan terhadap gosokan (Ruwana, 2008). 
Tabel 1. Hasil Rerata Uji Ketahanan Luntur Warna

\begin{tabular}{lcc} 
Jenis Mordan & Pencucian & $\begin{array}{c}\text { Sinar } \\
\text { Matahari }\end{array}$ \\
\hline Tanpa mordan & 3 & 3 \\
\hline Tawas & 4 & 4 \\
\hline Kapur sirih & 4 & 5 \\
\hline Tunjung & 5 & 5 \\
\hline $\begin{array}{l}\text { Keterangan: Nilai } \\
\text { sangat baik }\end{array}$ & \multicolumn{2}{l}{ cukup baik, $4=$ baik, $5=$} \\
\end{tabular}

Uji ketahanan luntur warna dilakukan guna mendapatkan hasil seberapa jauh daya tahan warna alami pada kain terhadap pengaruh pencucian dan paparan sinarmatahari. Berdasarkan uji ketahanan luntur, kain yang tidak ditambah mordan menunjukkan ketahanan luntur cukup baik dengan nilai 3 terhadap pengaruh pencucian dan paparan sinar matahari, karena penguncian zat warna pada serat kain kurang optimal sehingga ikatan dengan serat kurang sempurna. Penambahan mordan seperti tawas, kapur sirih, dan tunjung mengakibatkan ketahanan luntur terhadap pengaruh pencucian dan paparan sinar matahari meningkat yaitu memiliki kualitas baik sampai sangat baik dengan nilai 4 sampai 5. Hal tersebut terjadi karena adanya pemasukan dan penguncian zat warna pada serat kain dan membentuk ikatan dengan serat setelah pemberian mordan.

Dengan demikian, pemanfaatan daun harendong sebagai sumber pewarna alami dapat menambah daftar pewarna alternatif dalam industri tekstil. Potensi tersebut menjadikan salah satu keuntungan dari penggunaan harendong sebagai sumber zat pewarna alami agar tanaman tersebut terus dibudidayakan. Pemanfaatan daun juga dapat menjadi alternatif sumber pewarna alami, karena produktivitasnya jauh lebih tinggi dan tidak mengenal musim dibandingkan dengan organ lainnya. Selain itu, dengan memanfaatkan daun sebagai pewarna alami dapat mengurangi kelangkaan akibat kerusakan tumbuhan karena penggunaan akar atau batang tanaman.

\section{KESIMPULAN}

Daun harendong (Melastoma malabathricum) menghasilkan warna yang dapat digunakan untuk mewarnai kain katun. Warna yang dihasilkan dari ekstrak daun harendong bervariasi tergantung penggunaan mordan yaitu Banana (\#E3CF57) tanpa penambahan mordan, Khaki 1 (\#FFF68F) dengan penambahan mordan tawas, Lightgoldenrod 1 (\#FFEC8B) dengan mordan kapur sirih, dan penambahan tunjung menghasilkan warna Sgi Gray 36 (\#5B5B5B). Penambahan mordan juga berpengaruh baik terhadap ketahanan luntur warna melalui pengujian ketahanan luntur warna terhadap pencucian dengan sabun dan ketahanan luntur terhadap sinar terang matahari.

\section{UCAPAN TERIMAKASIH}

Ucapan terima kasih saya sampaikan kepada Prof. Mien Ahmad Rifai Ph.D dari Akademi Ilmu Pengetahuan Indonesia yang telah memberikan masukan dan bimbingan dalam penyempurnaan penulisan naskah ini dan Laboratorium Biologi Tumbuhan Pusat Penelitian Sumberdaya Hayati dan Bioteknologi (PPSHB) Institut Pertanian Bogor atas izin penelitian yang telah diberikan.

\section{DAFTAR PUSTAKA}

Bhattacharya, S. D., \& Shah, A. K. (2000). Metal ion effect on dyeing of wool 
fabric with cathecu. Coloration Technology, 116(1), 10-12.

El-Nagar, K., Sanad, S. H., Mohamed, A. S., \& Ramadan, A. (2005). Mechanical Properties and Stability to Light Exposure for Dyed Egyptian Cotton Fabrics with Natural and Synthetic Dyes. Polymer-Plastics Technology and Engineering, 44, 1269-1279.

Gholib, D. (2009). Uji Daya Hambat Daun Senggani (Melastoma malabathricum L.) terhadap Trichophyton mentagrophytees dan Candida albicans. Berita Biologi, 9(5), 523-527.

Goodarzian, H., \& Ekrami, E. (2010). Extraction of Dye from Madder Plant (Rubia tinctorium) and Dyeing of Wool. World Applied Sciences Journal, 9(4), 434-436.

Iqbal, J., Bhatti, I. A., \& Adeel, S. (2008). Effect of UV Radiation on Dyeing of Cotton Fabric with Extracts of Henna Leaves. Indian Journal of Fibre \& Textile Research, 33, 157-162.

Janna, O. A., Khairul, A., Maziah, M., \& Mohd, Y. (2006). Flower Pigment Analysis of Melastoma malabathricum. African Journal of Biotechnology, 5(2), 170-174.

Jothi, D. (2008). Extraction of Natural Dyes from African Marigold Flowers (Togetes ereectal) for Textile Coloration. AUTEX Research Journal, 8(2), 1-5.

Moiliet, J. L., \& Collie, B. (1951). Surface Activity. London: E \& F.N. Spon Ltd.

Prayitno, R. E., Wijana, S., \& Diyah, B. S. (2014). Pengaruh Bahan Fiksasi terhadap Ketahanan Luntur dan Intensitas Warna Kain Mori Batik Hasil Pewarnaan Daun Alpukat (Persea americana Mill.). Jurnal Jurusan Teknologi Industri Pertanian Fakultas Teknologi Pertanian Universitas Brawijaya, 1-8.

Pujilestari, T. (2014). Pengaruh Ekstraksi Zat Warna Alam dan Fiksasi terhadap Ketahanan Luntur Warna pada Kain Batik Katun. Dinamika Kerajinan Batik, 31(1), 1-9.
Russanti, I. (2007). Desain Kebaya Sunda Abad Ke-20 Studi Kasus di Bandung Tahun 1910-1980. ITB J. Vis. Art., 1(2), 196-210.

Ruwana, L. (2008). Pengaruh Zat Fiksasi terhadap Ketahanan Luntur Warna pada Proses Pencelupan Kain Kapas dengan Menggunakan Zat Warna dari Limbah Kayu Jati (Tectona grandis). Skripsi, Universitas Negeri Semarang, Semarang.

Samanta, A. K., \& Agarwal, P. (2009). Application of Natural Dyes on Textiles. Indian Journal of Fibre \& Textile Research, 34, 384-399.

See, K. S. (2008). Establishment of Cell Suspension Culture of Melastoma malabathricum L. for the Production of Anthocyanin. Disertasi, University Sains Malaysia, Graduate School of Biological Science, Pulau Pinang.

Singh, R., \& Srivastava, S. (2017). A Critical Review on Extraction of Natural Dyes from Leaves. International Journal of Home Science, 3(2), 100-103.

Sobandi, B. (2011). Eksplorasi Bahan Fiksasi untuk Menentukan Jenis dan Arah Warna pada Proses Pewarnaan Kain Batik dengan Zat Warna Alam (ZPA). Tesis, Universitas Pendidikan Indonesia, Fakultas Pendidikan Bahasa dan Seni, Bandung.

Sutara, P. K. (2009). Jenis Tumbuhan sebagai Pewarna Alam pada Beberapa Perusahaan Tenun di Gianyar. Jurnal Bumi Lestari, 9(2), 217-223.

Temani, P., Shakyawar, D. B., Ammayappan, L., Goyal, V., \& Wani, S. A. (2011). Standardization of Dyeing Condition of Chocineal Extract on Pashmina Yarn. Journal of the Textile Association, 72(2), 90-92.

Uddin, M. G. (2014). Effects of Different Mordants on Silk Fabric Dyed with Onion Outer Skin Extracts. Journal of Textiles, 1-8.

Uddin, M. G. (2015). Extraction of EcoFriendly Natural Dyes from Mango Leaves and Their Application on Silk 
Fabric. Textiles and Clothing Sustainability, 1(7), 1-8.

Vadwala, Y., \& Kola, N. (2017). Dyeing of

Nylon Fabric with Natural Dye

Extracted from Waste Leaves of

Terminalia catappa Locally Known as

Tropical Almond Tree. International Journal of Home Science, 3(2), 175181.

Vankar, P. S., Tiwari, V., Singh, L. W., \& Potsangbam, L. (2009). Sonicator
Dyeing of Cotton Fabric and Chemical Characterization of the Colorant from Melastoma malabathricum. Pigment \& Resin Technology, 38(1), 38-42.

Ventura-Camargo, B. d., \& Marin-Morales, M. A. (2013). Azo Dyes: Characterization and Toxicity Review. Textiles and Light Industrial Science and Technology (TLIST), 85-103. 
8| Dinamika Kerajinan dan Batik, Vol.35, No.1, Juni 2018,1-8 